\title{
Effect of backfat loss during lactation on weaning-to-oestrus interval of sows at gonadotropin application
}

\begin{abstract}
A total of 984 primiparous and multiparous crossbred sows (Swedish Landrace $\times$ Large White) housed on a commercial pig farm were used to study the effect of the decrease in backfat thickness during lactation and the level of backfat at weaning on weaning-to-oestrus interval and conception rate of sows. Primiparous sows $(n=213)$ received a single injection of $400 \mathrm{IU}$ eCG $+200 \mathrm{IU}$ hCG $\left(\right.$ PG600 ${ }^{\circledR}$, Intervet $)$ at weaning and approximately $30 \%$ of sows did not respond to the first treatment. First-farrowing sows produced significantly fewer live-born piglets, had markedly thinner backfat in late gestation, showed significant loss of backfat thickness during lactation and showed thinner backfat at weaning than sows with a greater number of parities. Primiparous sows with backfat thinner than $18 \mathrm{~mm}$ at weaning lost an average of $21 \%$ of backfat during lactation and had a significantly longer weaning-to-oestrus interval (31.75 \pm 2.22 days), even after a second treatment with $\mathrm{PG} 600^{\circledR}$, than both primiparous sows which responded to the first treatment $(5.95 \pm 0.16$ days) and multiparous sows which were not treated (5.19 \pm 0.12 days). The primiparous and multiparous sows with thicker backfat at farrowing also had thicker backfat at weaning ( $\mathrm{r}=0.874$ and $\mathrm{r}=0.938$ for primiparous and multiparous sows, respectively). Sows with thicker backfat at weaning showed a shorter weaning-to-oestrus interval and this correlation was higher for primiparous than for multiparous sows $(\mathrm{r}=-0.192$ and $\mathrm{r}=-0.100$, respectively). Thicker backfat of the sows at weaning was moderately but significantly correlated with lower loss of backfat during lactation $(\mathrm{r}=-0.179$ and $\mathrm{r}=-0.273$ for primiparous and multiparous sows, respectively). The present study showed that monitoring of backfat thickness and loss of backfat during lactation represents a useful tool to decrease non-productive days and improve the efficiency of high-producing pig herds.
\end{abstract}

$\underline{\text { Keywords: }}$ sow, gilts, backfat thickness, backfat loss, weaning to oestrus interval, conception rate, PG600 ${ }^{\circledR}$

\section{Zusammenfassung}

Titel der Arbeit: Einfluss der verminderter Rückenspeckdicke während der Laktation auf den AbsetzÖstrusintervall nach Gonadotropinapplikation bei Sauen

An 948 Kreuzungsjung- und Altsauen (Schwedische Landrasse $\times$ Large White) wurde die Minderung der Rückenspeckdicke während der Laktation, der Absetz-Östrusintervall und die Konzeptionsrate bei Gonadotropinapplikation untersucht. Die Jungsauen $(n=213)$ erhielten 24 Stunden nach dem Wurfabsetzen $400 \mathrm{IE} \mathrm{eCG}+200 \mathrm{IE} \mathrm{hCG} \mathrm{(Intervet)} \mathrm{injiziert.} \mathrm{30 \%} \mathrm{der} \mathrm{Saue} \mathrm{haben} \mathrm{nicht} \mathrm{auf} \mathrm{diese} \mathrm{Behandlung} \mathrm{reagiert.} \mathrm{Die}$ Jungsauen erreichten kleinere Würfe lebend geborener Ferkel, die Speckdicke insbesondere in der späten Trächtigkeitsphase war signifikant geringer und während der Laktation zeigte diese Gruppe den größeren Rückgang der Speckdicke als die Altsauen. Jungsauen deren Speckdicke weniger als $18 \mathrm{~mm}$ betrug, verloren während der Laktation 21 \% der Speckdicke, zeigte einen größeren Absetz-Östrusintervall trotz einer zweiten Behandlung mit $P G 600^{\circledR}$. Sowohl Jung- als auch Altsauen die bei der ersten Abferkelung eine größere Speckdicke aufwiesen behielten auch nach dem Absetzen die größeren Speckdicken. Sauen mit größeren Speckdicken zeigten einen kürzeren Zeitraum zwischen dem Absetzen und dem Östruseintritt. Diese Beziehung war bei Jungsauen stärker ausgeprägt als bei Altsauen. Die Untersuchung ergab, dass eine Erfassung der Rückenspeckdicke der Sauen und deren Veränderung während der Laktation eine Möglichkeit bietet die unproduktiven Tage einzuschränken.

Schlüsselwörter: Jungsau, Altsau, Rückenspeckdicke, Verminderung der Rückenspeckdicke, Absetz-Östrus intervall, Konzeptionsrate, PG600 ${ }^{\circledR}$ 


\section{Introduction}

The weaning-to-oestrus interval corresponds to the period between the day of weaning and the first day the sow is showing standing heat. It is influenced by lactation length (POLEZE et al., 2006) and lactation weight loss (THAKER and BILKEI, 2005), parity number (HEIDLER and HENNE, 1989), litter size (for review see, EISSEN et al., 2000), season (PRUNIER, 1996), nutrition (WHITTEMORE, 1996), genetics (for review see RYDHMER, 2000), disease status and management (DIAL et al., 1992).

However, sows that fail to return to oestrus and receive insemination within 7 days of weaning have reduced reproductive performance and this leads to a higher number of non-productive days in females (KOKETSU, 2005). The variability in the duration of the weaning-to-oestrus interval can influence the ability to meet high farm production targets (DE RENNIS et al., 2003). Thus, to enhance reproductive efficiency and to substantially reduce costs in the breeding herd, the number of such days needs to be minimized (ESTIENNE and HARTSOCK, 1998).

The introduction of gilts into the herd and initiation of their reproductive cycle before they acquire sufficient body fat reserves is very often related to the decrease in body fat at farrowing (WHITTEMORE, 1996). Moreover, sows that end the lactation period with excess weight loss or decreased backfat thickness can be expected to have a longer weaning-to-oestrus interval in the next cycle of reproduction, as well as a decreased level of conception at the following mating (EISSEN et al., 2000). As a solution to this problem, a system of biotechnical interventions has been developed (for review see KÖNIG and HÜHN, 1997; WÄHNER, 2002) and especially for young sows after first lactation, the use of the oestrus-inducing drug, PG600 ${ }^{\circledR}$, at weaning has been suggested (VARGAS et al., 2006).

To our knowledge, the effect of the loss of backfat thickness during lactation and the consequent increase in weaning-to-oestrus interval, even after PG600 ${ }^{\circledR}$ has been administered at weaning, has not previously been examined. The present study was therefore conducted to investigate the effect of the decrease in backfat thickness during lactation and the effect of backfat thickness at weaning on the weaning-to-oestrus interval, conception rate, percentage of anoestrus sows and culling rate in primiparous and multiparous sows during the spring. All first-farrowing sows had been stimulated with PG600 ${ }^{\circledR}$ on the day following weaning.

\section{Materials and methods}

\section{Animals}

A total of 984 primiparous and multiparous crossbred Swedish Landrace $\times$ Large White sows in a high-producing commercial herd were analysed. The gilts were successfully inseminated between the ages of 245 and 266 days. The study was conducted during the spring (March-June 2006).

\section{Housing and management}

During gestation sows were kept in group pens. The pens measured $3.6 \times 4.8 \mathrm{~m}(12$ sows per pen; i.e. $1.25 \mathrm{~m}^{2}$ per sow). Automatic feeding was carried out once per day, in the morning. The feeding troughs were $60 \mathrm{~cm}$ long $\times 30 \mathrm{~cm}$ wide $\times 20 \mathrm{~cm}$ high . Artificial light $(601 \mathrm{x})$ was provided. The sows had ad libitum access to water (automatic nipple watering). 
Between day 109 and 112 of gestation the animals were moved into a farrowing house equipped with individual farrowing crates where they remained during the lactation period which lasted 23 days. The newborn piglets were cross-fostered 5-12 h after they were born to give 10 to 12 piglets per litter, taking into account the number of functional teats of each sow, the number of weaned piglets in previous lactations, and the general condition of each sow.

The size of a single farrowing pen was $2.4 \mathrm{~m} \times 1.6 \mathrm{~m}\left(3.84 \mathrm{~m}^{2}\right)$. Artificial light $(60 \mathrm{~lx})$ was provided. The floor of the farrowing area was equipped with a plastic grate $(1 \mathrm{~cm} \times 5 \mathrm{~cm}$ mesh). One area of each farrowing pen was equipped with a special heating plate for piglets $(150 \mathrm{~cm}$ long; $60 \mathrm{~cm}$ wide at one end tapering to $21 \mathrm{~cm}$ at the other) along with an infrared light. The feeding troughs for sows were $38 \mathrm{~cm}$ long $\times$ $40 \mathrm{~cm}$ wide $\times 20 \mathrm{~cm}$ high. Feed withdrawal was implemented on the day of farrowing. On the $5^{\text {th }}$ to $7^{\text {th }}$ day after parturition, the piglets received pre-starter feed in special feeding troughs $(16 \mathrm{~cm} \times 34 \mathrm{~cm} \times 14 \mathrm{~cm})$. Sows and piglets had ad libitum access to water (automatic nipple watering).

After weaning, sows were transferred to the service area, i.e. individual pens with an area of $1.92 \mathrm{~m}^{2}(2.15 \mathrm{~m} \times 0.6 \mathrm{~m})$ with concrete rifts. The sows were fed once daily using feeding machines that transferred the feed into the feeding troughs $(60 \mathrm{~cm} \times 30 \mathrm{~cm} \times 20 \mathrm{~cm})$. The area was provided with artificial light at $330 \mathrm{~lx}$ for $16 \mathrm{~h}$ per day. The readiness of the sows for mating was tested daily by exposure to a boar.

\section{Data collection}

Backfat thickness measurement

Backfat thickness was measured using an ultrasound apparatus (Backfat Scanner, Draminski, Poland). Measurements were conducted at two points during the reproductive cycle, i.e. 5 days before expected farrowing and at weaning (after 23 days of lactation). The measurements were performed in the back area at the last rib, 5-8 cm lateral to the dorsal midline. Before the measurement, the selected area was shaved, designated with a colour marker and oiled with paraffin oil. The designation of measurement areas on each individual sow enabled us to perform every measurement at exactly the same point. The average of three successive measurements was taken (triple mode).

Feeding of sows and composition of diet during gestation and lactation

Feeding of sows and gilts during gestation was carried out automatically using feeding machines. Older sows and gilts were given different feed mixtures. For pregnant sows, the feed contained $12.3 \mathrm{MJ} / \mathrm{kg}$ of metabolisable energy, $13.5 \%$ crude protein and $0.7 \%$ lysine (Table 1). For pregnant gilts, the feed contained $13.0 \mathrm{MJ} / \mathrm{kg}$ metabolisable energy with $15.5 \%$ crude protein and $0.8 \%$ lysine (Table 1 ). Noninseminated gilts were given $3.1 \mathrm{~kg}$ feed daily. This amount was reduced to $2.5 \mathrm{~kg}$ during the oestrous period, whereas for pregnant gilts the amount was gradually increased up to $3.9 \mathrm{~kg}$. From weaning to oestrus, older sows were given $3.0 \mathrm{~kg}$ feed daily. The amount of feed given to older sows was also reduced at oestrus, to $2.4 \mathrm{~kg}$ daily. Up to day 59 of gestation, the amount of feed given to older sows was gradually increased up to $2.7 \mathrm{~kg}$ daily. From day 60 to day 84 of gestation, the amount was further increased to $3.9 \mathrm{~kg}$ daily. During late pregnancy, from day 85 , the amount of daily feed offered to multiparous sows increased by an additional $0.3 \mathrm{~kg}$ daily to reach a total of $4.2 \mathrm{~kg}$ per day. 
Table 1

Composition of the feed used during gestation and lactation

(Futterzusammensetzung während der Tragezeit und der Laktation)

\begin{tabular}{lccc}
\hline \multirow{2}{*}{ Nutrient composition } & \multicolumn{2}{c}{ Gestation } & \multicolumn{2}{c}{ Lactation } \\
\hline Crude protein, $\%$ & Sows & Gilts & Sows \\
Crude fat, $\%$ & 13.5 & 15.5 & 3.0 \\
Crude fibre, $\%$ & 3.0 & 4.5 & 6.5 \\
Crude ash, \% & 7.5 & 7.0 & 5.5 \\
Lysine, $\%$ & 5.5 & 6.0 & 0.95 \\
Metabolisable energy, $\mathrm{MJ} / \mathrm{kg}$ & 0.7 & 0.8 & 13.0 \\
\hline
\end{tabular}

After moving the sows into the farrowing area we started feeding them with the complete feed mixture for lactating sows that differed in composition from the feed mixture used for pregnant sows or gilts (Table 1). The feed for lactating sows contained $13 \mathrm{MJ} / \mathrm{kg}$ of metabolisable energy, $17 \%$ crude protein, and $0.95 \%$ lysine.

On day 113 of gestation the sows were given $2 \mathrm{~kg}$ of feed, whereas on day 114 and day 115 of gestation the amount was decreased to $1 \mathrm{~kg}$. At this time, the sows were expected to give birth to piglets. On the first day after farrowing the daily amount of feed was increased, and on days 6 and 7 of lactation sows were given $4 \mathrm{~kg}$ of feed mixture, divided into two feedings per day. On days 8 and 9 of lactation the sows were fed three times a day and consequently the amount of feed was increased to $6 \mathrm{~kg}$ per day. From days 10 to 12 of lactation sows were given the maximum amount of feed mixture (up to $6.5 \mathrm{~kg}$ ), depending on their appetite. The maximum amount of feed was administered until 3 days before weaning, when the daily amount offered was gradually reduced. Thus, 3 days before weaning sows were given $4 \mathrm{~kg}$ of feed daily, 2 days before weaning, $2.5 \mathrm{~kg}$, and on the day before weaning, only $1 \mathrm{~kg}$.

Insemination of sows and gestation control

Sows with detectable oestrus were artificially inseminated on the same day. The insemination was repeated after $20 \mathrm{~h}$. In the case of re-inseminated sows, the control of gestation was undertaken on day 25 to 27 after insemination using ultrasound equipment (Agroscan, ECM, France).

\section{Hormonal stimulation}

All primiparous sows $(\mathrm{n}=213)$ were treated with $5 \mathrm{~mL}$ of a combination of $400 \mathrm{IU}$ $\mathrm{eCG}+200 \mathrm{IU}$ hCG (injection of gonadotrophin [PG600 ${ }^{\mathbb{B}}$, Intervet, Netherlands]), $24 \mathrm{~h}$ after weaning. One group of primiparous sows $(n=63)$ which did not return to oestrus within 6 days after treatment were subjected to secondary synchronization using the same dose of $\mathrm{PG} 600^{\circledR}$. Multiparous sows failing to show signs of oestrus by the $19^{\text {th }}$ day after weaning were also treated with an injection of gonadotrophin PG600 ${ }^{\circledR}$, but they were excluded in the data analyses.

\section{Statistical analysis}

All data were analysed using SPSS 15.0.1 for Windows. Data relating to litter size (total piglets born, live-born piglets, piglets born dead), backfat measurements (backfat at farrowing, backfat at weaning and backfat loss during lactation) and weaning-to-oestrus interval were analysed using analysis of variance (ANOVA). The statistical model included parity as a fixed effect. Primiparous sows were divided into those which had received PG600 ${ }^{\circledR}$ once and those which had received it twice. 
Multiparous sows (received no hormone treatment) formed a further group. The effects of backfat thickness at weaning and magnitude of the decrease in backfat during lactation, on the subsequent weaning-to-oestrus period, were assessed using ANOVA. Backfat loss during lactation of multiparous and first-farrowing sows was also calculated as a percentage. Percentage anoestrus was evaluated as percentage of sows not in oestrus after day 10 of treatment according to BATES et al. (1991). Using the SPSS 15.0 for Windows, Pearson's correlation coefficients were estimated between backfat at farrowing, backfat at weaning, loss of backfat thickness and weaning-to-oestrus interval, separately for first farrowing sows and multiparous sows. Multiple comparisons between means were made using the post-hoc LSD test, with a significance level at $\mathrm{p}<0.05^{*}, \mathrm{p} \leq 0.01^{* *}$ or $\mathrm{p} \leq 0.001^{* * *}$. The values in the tables are presented as observed mean \pm standard error of mean.

\section{Results}

\section{Litter size and backfat thickness}

First farrowing sows had the smallest number of live-born piglets (Table 2).

Table 2

Litter size and comparison of backfat thickness at farrowing and weaning at different parities (Wurfgröße und Vergleich der Rückenspeckdicke bei der Abferkelung und dem Absetzen der Sauen bei aufeinander folgenden Abferkelungen)

\begin{tabular}{cccccccc}
\hline Parity & $n$ & Piglets born & Live-born piglets & $\begin{array}{c}\text { Piglets born } \\
\text { dead }\end{array}$ & $\begin{array}{c}\text { Backfat at } \\
\text { farrowing }(\mathrm{mm})\end{array}$ & $\begin{array}{c}\text { Backfat at } \\
\text { weaning }(\mathrm{mm})\end{array}$ & $\begin{array}{c}\text { Change in backfat } \\
\text { thickness }(\mathrm{mm})\end{array}$ \\
\hline 1 & 213 & $10.11 \pm 0.17^{\mathrm{a}}$ & $9.64 \pm 0.17^{\mathrm{a}}$ & $0.47 \pm 0.06^{\mathrm{a}}$ & $23.27 \pm 0.29^{\mathrm{a}}$ & $19.65 \pm 0.31^{\mathrm{a}}$ & $3.62 \pm 0.15^{\mathrm{a}}$ \\
2 & 222 & $11.05 \pm 0.19^{\mathrm{ac}}$ & $10.68 \pm 0.18^{\mathrm{b}}$ & $0.37 \pm 0.05^{\mathrm{b}}$ & $24.05 \pm 0.37^{\mathrm{a}}$ & $20.86 \pm 0.36^{\mathrm{b}}$ & $3.19 \pm 0.14^{\mathrm{b}}$ \\
3 & 173 & $11.52 \pm 0.18^{\mathrm{bc}}$ & $11.20 \pm 0.19^{\mathrm{c}}$ & $0.32 \pm 0.04^{\mathrm{b}}$ & $25.95 \pm 0.42^{\mathrm{b}}$ & $22.69 \pm 0.45^{\mathrm{c}}$ & $3.26 \pm 0.18^{\mathrm{ab}}$ \\
4 & 115 & $11.49 \pm 0.29^{\mathrm{bc}}$ & $10.82 \pm 0.27^{\mathrm{bc}}$ & $0.67 \pm 0.10^{\mathrm{a}}$ & $27.46 \pm 0.57^{\mathrm{c}}$ & $24.61 \pm 0.64^{\mathrm{d}}$ & $2.85 \pm 0.23^{\mathrm{bc}}$ \\
5 & 97 & $12.02 \pm 0.26^{\mathrm{b}}$ & $11.38 \pm 0.27^{\mathrm{c}}$ & $0.64 \pm 0.08^{\mathrm{a}}$ & $28.91 \pm 0.70^{\mathrm{dc}}$ & $26.45 \pm 0.75^{\mathrm{e}}$ & $2.45 \pm 0.23^{\mathrm{bd}}$ \\
6 & 79 & $11.91 \pm 0.28^{\mathrm{b}}$ & $11.32 \pm 0.26^{\mathrm{bc}}$ & $0.59 \pm 0.10^{\mathrm{a}}$ & $29.20 \pm 0.68^{\mathrm{d}}$ & $26.51 \pm 0.74^{\mathrm{e}}$ & $2.70 \pm 0.30^{\mathrm{be}}$ \\
7 & 45 & $11.96 \pm 0.33^{\mathrm{b}}$ & $11.07 \pm 0.32^{\mathrm{bc}}$ & $0.89 \pm 0.18^{\mathrm{a}}$ & $30.27 \pm 1.13^{\mathrm{d}}$ & $28.10 \pm 1.26^{\mathrm{e}}$ & $2.18 \pm 0.31^{\mathrm{bf}}$ \\
$\geq 8$ & 40 & $11.68 \pm 0.49^{\mathrm{b}}$ & $11.14 \pm 0.39^{\mathrm{bc}}$ & $0.55 \pm 0.18^{\mathrm{ab}}$ & $28.73 \pm 1.68^{\mathrm{cd}}$ & $25.73 \pm 1.71^{\mathrm{de}}$ & $3.00 \pm 0.55^{\mathrm{ab}}$ \\
\hline
\end{tabular}

Sows at their first or second farrowing had statistically fewer live-born piglets than sows at their fifth and subsequent farrowing. Apart from the sows at their second farrowing, the gilts had statistically thinner backfat layers at farrowing in comparison to sows at later farrowings. The sows at their third farrowing had statistically thicker backfat than sows at the first or second farrowing, and statistically thinner backfat than sows with 4 or more successive farrowings. Sows at their fourth farrowing had thinner backfat than sows with 5 or more farrowings (Table 2).

At weaning, the gilts had a significantly thinner backfat layer, followed by sows at their second or third farrowing (Table 2). Sows at their fourth farrowing had a statistically thicker backfat layer than sows at the first, second and third farrowing, but a thinner backfat layer than sows at the fifth, sixth and seventh farrowings. Sows at their fourth farrowing had a similar backfat thickness as sows at their eighth farrowing. Sows at their fifth, sixth, or seventh farrowing showed no statistically significant differences in backfat thickness in late gestation ( 5 days before expected farrowing), but these sows had significantly thicker backfat than all groups up to the fourth farrowing and similar backfat thickness to sows with eight farrowings or more. 
During the lactation period, primiparous sows lost the most backfat, and also had the thinnest backfat at weaning. A similar decrease was seen only in the sows with eight farrowings or more (Table 2). Among the sows at their second and third farrowing there were no statistically significant differences in backfat thickness at weaning. These sows also lost less backfat during lactation than primiparous sows. However, the decrease in backfat thickness was still greater than in sows at their fifth and sixth farrowings. Sows at their fourth farrowing lost more backfat than primiparous sows, whereas in comparison with the other groups their losses were statistically nonsignificant. Sows at their fifth, sixth and seventh farrowings lost less backfat during lactation than primiparous sows. Sows at their fifth successive farrowing did not differ statistically from the other groups regarding their decrease in backfat thickness.

\section{Backfat thickness and weaning-to-oestrus interval}

All primiparous sows with a backfat thickness at weaning of less than $18 \mathrm{~mm}$ and $21 \%$ loss of backfat during lactation received a second $P G 60{ }^{\circledR}$ administration and they had also a significantly longer weaning-to-oestrus interval in comparison with primiparous sows with only one PG600 ${ }^{\circledR}$ treatment and multiparous sows without treatment (Table 3).

Table 3

Reproduction in primiparous sows following the first and second treatment with PG600 ${ }^{\circledR}$ at weaning and in multiparous sows (which were not treated) (Einige Reproduktionsmerkmale von Sauen nach der ersten Abferklung und der Applikation von PG600 ${ }^{\circledR}$ beim Absetzen im Vergleich zu den Altsauen ohne PG600 ${ }^{\circledR}$ )

\begin{tabular}{|c|c|c|c|}
\hline \multirow[b]{2}{*}{ Items } & \multicolumn{2}{|c|}{ Primiparous sows } & \multirow{2}{*}{$\begin{array}{l}\text { Multiparous sows } \\
\text { Without treatment }\end{array}$} \\
\hline & $\begin{array}{l}\text { First treatment } \\
\text { with PG600 }\end{array}$ & $\begin{array}{l}\text { Second treatment } \\
\text { with PG600 }\end{array}$ & \\
\hline$\overline{\text { Number of females }}$ & 150 & 63 & 771 \\
\hline Backfat at weaning (mm) & $20.44 \pm 0.36^{\mathrm{a}}$ & $17.41 \pm 0.55^{\mathrm{b}}$ & $23.71 \pm 0.25^{\mathrm{c}}$ \\
\hline Loss of backfat thickness $(\%)$ & $14.16 \pm 0.78^{\mathrm{a}}$ & $20.90 \pm 1.27^{\mathrm{b}}$ & $11.64 \pm 0.33^{\mathrm{c}}$ \\
\hline Weaning-to-oestrus (days) & $5.95 \pm 0.16^{\mathrm{a}}$ & $31.75 \pm 2.22^{\mathrm{b}}$ & $5.19 \pm 0.12^{\mathrm{a}}$ \\
\hline Anoestrus $(\%)$ & $5.3^{\mathrm{a}}$ & $100^{\mathrm{b}}$ & $3.5^{\mathrm{a}}$ \\
\hline Conception rate $(\%)$ & $89^{\mathrm{a}}$ & $86^{\mathrm{a}}$ & $94^{\mathrm{a}}$ \\
\hline Culling rate $(\%)$ & & & $5.5^{\mathrm{a}}$ \\
\hline
\end{tabular}

$\mathrm{a}, \mathrm{b}, \mathrm{c}=$ values signed with different letters in the row are significantly different $(\mathrm{p}<0.05)$

Moreover, the sows which received a second dose of PG600 ${ }^{\circledR}$ not only lost the greatest proportion of their backfat during lactation and had significantly longer weaning-to-oestrus intervals, but they also had a significantly longer anoestrus than primiparous sows which only received one PG600 ${ }^{\circledR}$ treatment and the non-treated multiparous sows. No significant differences were found in conception rate and culling rate between first farrowing sows and multiparous sows.

Relationships between reproductive performance of primiparous and multiparous sows were estimated using Pearson's correlation coefficients (Table 4 and 5).

Backfat thickness of primiparous sows at farrowing was significantly positively correlated with backfat thickness at weaning, but was significantly negative correlated with the loss of backfat thickness during lactation and the weaning-to-oestrus interval. The latter two correlations were weak, especially in comparison to the relationship between backfat at weaning and loss of backfat during lactation. Increasing loss of backfat thickness during lactation was associated with a significant increase in weaning-to-oestrus interval (Table 4). 
Table 4

Pearson's correlation coefficients between backfat thickness at farrowing, backfat thickness at weaning, loss of backfat thickness during lactation and weaning-to-oestrus interval of primiparous sows (Pearsons Korrelationskoeffizient zwischen der Rückenspeckdicke bei Abferklung und beim Absetzen, und dem Verlust der Rückenspeckdicke während der Laktation und dem Zeitraum ab dem Absetzen bis zum Östrus bei den Sauen, die das erste Mal abferkelten)

\begin{tabular}{|c|c|c|c|c|}
\hline Items & $\mathrm{BF}$ & BW & LBF & WOI \\
\hline Backfat at farrowing (BF) & 1 & $0.874^{* *}$ & $-0.179^{* *}$ & $-0.192^{* *}$ \\
\hline Backfat at weaning (BW) & & 1 & $-0.626^{* *}$ & $-0.283^{* *}$ \\
\hline Loss of backfat thickness (LBF) & & & 1 & $0.288^{* *}$ \\
\hline Weaning-to-oestrus interval (WOI) & & & & 1 \\
\hline
\end{tabular}

${ }^{* *}$ Correlation is significant at the 0.01 level (2-tailed)

The backfat thickness at farrowing of multiparous sows was highly and significant correlated with backfat thickness at weaning. Increased backfat thickness at farrowing was associated with a significant loss of backfat thickness during lactation and decreased the weaning-to-oestrus interval. Loss of backfat thickness was significantly positively correlated with weaning-to-oestrus interval (Table 5).

Table 5

Pearson's correlation coefficients between backfat thickness at farrowing, backfat thickness at weaning, loss of backfat thickness during lactation and weaning-to-oestrus interval of multiparous sows

(Pearsons Korrelationskoeffizient zwischen den Rückenspeckdicke bei Abferkelung und beim Absetzen sowie dem Verlust der Rückenspeckdicke während der Laktation und dem Zeitraum ab dem Absetzen bis zum Östrus bei den Sauen, die mehrere Male abferkelten)

\begin{tabular}{|c|c|c|c|c|}
\hline Items & $\mathrm{BF}$ & $\mathrm{BW}$ & LBF & WOI \\
\hline Backfat at farrowing (BF) & 1 & $0.938^{* *}$ & $-0.273^{* *}$ & $-0.100^{* *}$ \\
\hline Backfat at weaning (BW) & & 1 & $-0.577^{* *}$ & $-0.127^{* *}$ \\
\hline Loss of backfat thickness (LBF) & & & 1 & $0.153^{* *}$ \\
\hline Weaning-to-oestrus interval (WOI) & & & & 1 \\
\hline
\end{tabular}

${ }^{* *}$ Correlation is significant at the 0.01 level (2-tailed)

\section{Discussion}

The present study confirmed that the number of live-born piglets increased with successive parities up to 5 (ČECHOVÁ and TVRDOŇ, 2006). The primiparous sows had in average 9.64 live-born piglets, but using cross-fostering in the present study they had the same number of suckling piglets as multiparous sows (10 piglets). Therefore, they reared more piglets and they had to maintain their own growth as well as continued milk production.

Backfat measurements constitute a valuable tool to monitor and improve the productivity and efficiency of high-producing herds (MAES et al., 2004). Several authors have reported that age and backfat thickness are important for gilts' fertility performance. The gilts with the largest fat thickness before start of breeding yield the best fertility performance (TUCHSCHERER and HÜHN, 1997; WÄHNER et al., 2001b; BEČKOVÁ et al., 2005) and have a higher number of litters (ČECHOVÁ and TVRDOŇ, 2006). The side fat thickness of gilts at the time of insemination has a significant effect on reproductive performance (KÄMMERER et al., 1998, JOHN et al., 2001). Moreover, gilts with a fat thickness of 13-18 $\mathrm{mm}$ yield higher farrowing rates and piglet numbers per 100 inseminated animals than gilts with less fat thickness (HÜHN, 1997). Due to the increased energetic needs during lactation many sows enter into a state of negative energetic balance where body fat reserves are catabolised (VALROS et al., 2003). Together with the limited body fat reserves of contemporary pig breeds, the 
extensive catabolism of body reserves can have a negative influence on the duration of the weaning-to-oestrus period (YANG et al., 1989; STERNING et al., 1990; PRUNIER et al., 1993; TANTASUPARUK et al., 2001a; THAKER and BILKEI, 2005). Data from several studies have shown that backfat levels lower than $14 \mathrm{~mm}$ (YOUNG et al., 1991; HUGHES, 1993; TANTASUPARUK et al., 2001b) and thicker than $25 \mathrm{~mm}$ affect subsequent reproductive performance of sows (WHITTEMORE, 1996; WÄHNER et al., 2001a). It has been suggested that sows with a backfat thickness at weaning between $19 \mathrm{~mm}$ and $23 \mathrm{~mm}$ reach the best reproductive performance in their next reproductive cycle (WÄHNER et al., 2001a). In the present study, results of backfat thickness at weaning of primiparous and multiparous sows and their relationship with reproduction are in agreement with previous reports. The present study showed that primiparous and multiparous sows with a thicker backfat at farrowing also had thicker backfat at weaning. Sows with thicker backfat at weaning showed a shorter weaning-to-oestrus interval and this correlation was higher for primiparous than for multiparous sows. Furthermore, sows with thicker backfat at weaning also lost less backfat during lactation. The present results also showed that primiparous sows with a backfat thickness of less than $18 \mathrm{~mm}$ at weaning together with $21 \%$ loss of backfat thickness during lactation showed a significantly longer weaning-to-oestrus interval and lower conception rate than sows with thicker backfat at weaning, even after a second treatment with $\mathrm{PG} 600^{\circledR}$. Furthermore, 30\% of first-farrowing sows showed post-weaning anoestrus and required an additional secondary hormonal synchronization. After the initial PG600 ${ }^{\circledR}$ treatment of primiparous sows only $5.3 \%$ of the sows showed anoestrus. Despite a second PG600 ${ }^{\circledR}$ treatment, first-farrowing sows showed an approximately 5-fold longer weaning-to-oestrus interval than both primiparous sows which responded to the first $\mathrm{PG} 600^{\circledR}$ treatment and multiparous sows which were not treated with $\mathrm{PG} 600^{\circledR}$. One possible explanation is that the prolongation of weaning-to-oestrus interval in these sows was caused by their thinner backfat at weaning and consequently their lower concentration of 17- $\beta$-estradiol in the thinner backfat layer (WÄHNER et al., 1995). It was apparent that a considerable number of primiparous sows were not able to overcome their nutrient deficit by mobilizing body reserves. The first parity sows had not reached their mature size and weight and they also consumed less feed than multiparous sows during lactation (WHITTEMORE, 1996). However, first lactating sows may not receive sufficient nutrients for optimal reproductive performance. It has been reported that sows consuming less than $3.5 \mathrm{~kg}$ of feed per day during the first two weeks of lactation are more likely to be removed from the herd before the next parity (ANIL et al., 2006).

Nevertheless, multiparous sows lost less backfat thickness $(\sim 12 \%)$ during lactation, but this decrease was not compensated by a corresponding increase in weaning-tooestrus interval (Table 3). It is possible that the substantial fat loss during lactation is accompanied by protein loss although recent work has shown no decline in lactation performance and ovarian function when a sow loses approximately 9 to $12 \%$ of its parturition protein mass (CLOWES et al., 2003). In other work, a reduction in lactation feed intake and oestrus delay has been reported due to high ambient temperatures and long photoperiod in summer (PRUNIER et al., 1996). However, in the present study the average temperature in spring (March-June) was between $7^{\circ} \mathrm{C}$ and $22^{\circ} \mathrm{C}$. We therefore assumed that temperature did not influence lactation feed intake and the weaning-to-oestrus interval. 
A prolonged interval between weaning and oestrus has been shown to decrease embryo survival rates and numbers of live-born piglets at the next pregnancy (EINARSSON and ROJKITTIKHUN, 1993; STERNING and LUNDEHEIM, 1995; WHITTEMORE, 1996). Longer weaning-to-oestrus periods are also associated with earlier culling (SIMMINS et al., 1994; SOLANES and STERN, 2001) and therefore a shorter productive lifetime (GAUGHAN et al., 1995; SERENIUS et al., 2006). In a large-scale experiment it has been reported that breed and subsequent parity significantly affect sow culling rates. In a previous study, approximately $18-30 \%$ sows were culled after first weaning from the studied herds because of reproductive problems (HEUSING et al., 2003). The percentage of culled primiparous and multiparous sows with serious reproductive problems in the present study was low in comparison with the previously mentioned trial. These low values were probably associated with a shorter study period for sows in our experiment. Moreover, lower culling rates than $20 \%$ at first parity would be recommended for producers aiming for a high-longevity and high-efficiency herd (KOKETSU, 2007).

The results of the present study clearly demonstrated significant effects of backfat thickness at weaning and lactation backfat loss of sows on successful management of their reproduction and the reduction of non-productive days. In the case of gilts, an excessively thin backfat layer $(<18 \mathrm{~mm})$ at weaning and significant losses in backfat thickness $(21 \%)$ during lactation caused longer weaning-to-oestrus intervals and lower conception rates even after treatment with $\mathrm{PG} 600^{\circledR}$. For multiparous sows, this association was less obvious.

\section{Acknowledgements}

This study was carried out according to the Law Regulating the Protection of Animals in the Republic of Slovenia (1999). The authors thank the staff at the pig farm on which this study was conducted for excellent care of the pigs. The Slovenian Research Agency and Ministry of Agriculture, Forestry and Food (Project V4-0338) are acknowledged for financial support.

\section{References}

ANIL, S.S.; ANIL, L.; DEEN, J.; BAIDOO, S.K.; WALKER, R.D:

Association of inadequate feed intake during lactation with removal of sows from the breeding herd. J. Swine Health Prod. 14 (2006), 296-301

BATES, R.O.; DAY, B.N.; BRITT, J.H.; CLARK, L.K.; BRAUER, M.A.: Reproductive performance of sows treated with a combination of pregnant mare's serum gonadotropin and human chorionic gonadotropin at weaning in the summer. J. Anim. Sci. 69 (1991), 894-898

BEČKOVÁ, R.; DANĚK, P.; VÁCLAVKOVÁ, E.; ROZKOT, M.:

Influence of growth rate, backfat thickness and meatiness on reproduction efficiency in Landrace gilts. Czech. J. Anim. Sci. 50 (2005), 535-544

CLOWES, E.J.; AHERNE, F.X.; FOXCROFT, G.R.; BARACOS, V.E.:

Selective protein loss in lactating sows is associated with reduced litter growth and ovarian function. J. Anim. Sci. 81 (2003), 753-764

ČECHOVÁ, M.; TVRDOŇ, Z.:

Relationships between backfat thickness and parameters of reproduction in the Czech Large White sows (short communication). Arch. Tierz. 49 (2006), 363-369

DE RENNIS, F.; BENEDETTI, S.; SILVA, P.; KIRKWOOD, R.N.:

Fertility of sows following artificial insemination at a gonadotrophin-induced estrus coincident with weaning. Anim. Reprod. Sci. 76 (2003), 245-250 
DIAL, G.D.; MARSH, W.E.; POLSON, D.D.; VAILLANCOURT, J.-P.:

Reproductive failure: differential diagnosis. In: Leman, A.D.; Straw, B.E.; Mengeling, W.L.; D'allaire, S.; Taylor, D.J. (Eds): Diseases of swine, $7^{\text {th }}$ ed. Ames (1992), 88-137

EINARSSON, S.; ROJKITTIKHUN, T.: Effects of nutrition on pregnant and lactating sows. J. Reprod. Fertil. Suppl. 48 (1993), 229-239

EISSEN, J.J.; KANIS, E.; KEMP, B.: Sow factors affecting voluntary feed intake during lactation. Livest. Prod. Sci. 64 (2000), 147-165

ESTIENNE, M.J.; HARTSOCK, T.G.: Effect of exogenous gonadotropins on the weaning-to-estrus interval in sows. Theriogenology 49 (1998), 823-828

GAUGHAN, J.B.; CAMERON, R.D.A.; DRYDEN, G.M.L.; JOSEY, M.J.:

Effect of selection for leanness on overall reproductive-performance in large white sows. Anim. Sci. 61 (1995), 561-564

HEIDLER W.; HENNE, I.:

Die mit Ultraschall gemessenen Gewebedicken von Sauen und deren Beziehungen zu ausgewählten Fruchtbarkeits- und Aufzuchtleistungen. Arch. Tierz. 32 (1989), 555-563

HEUSING, M.; HAMANN, H.; DISTL, O.:

Abgangsursachen und ihr Einfluss auf die Lebensleistung bei Sauen der Rassen Deutsches Edelschwein, Deutsche Landrasse und Pietrain. Arch. Tierz. 46 (2003), 569-583

HUGHES, P.E.:

The effects of food level during lactation and early gestation on the reproductive performance of mature sows. Anim. Prod. 57 (1993), 437-446

HÜHN, U.:

Zum Einfluß der Körperkondition von Jungsauen auf deren Erstabferkelleistungen nach biotechnischer Zyklussynhronisation. Arch. Tierz. 40 (1997), 25-34

JOHN, A.; WAEHNER, M.; HOFFMEYER, C.:

Zum Einfluss des Wachstums und der Seitenspeckdicke auf die Fruchtbarkeits- und Aufzuchtleistung von Jungsauen. 2. Mitteilung: Beziehungen zwischen den Merkmalen und Diskussion. Arch. Tierz. 44 (2001), 277-290

KÄMMERER, B.; MÜLLER, S.; HÜHN, U.:

Fruchtbarkeits- und Aufzuchtleistungen von Jungsauen mit unterschiedlicher Seitenspeckdicke zu Beginn ihrer Zuchtbenutzung. Arch. Tierz. 41 (1998), 387-396

KOKETSU, Y.:

Six component intervals of nonproductive days by breeding-female pigs on commercial farms. J. Anim. Sci. 83 (2005), 1406-1412

KOKETSU, Y.:

Longevity and efficiency associated with age structures of female pigs and herd management in commercial breeding herds. J. Anim. Sci. 85 (2007), 1086-1091

KÖNIG, I.; HÜHN, I.:

Zur Steuerung der Fortpflanzung bei Sauen - Eine Retrospektive. Arch. Tierz. 40 (1997), 239-256

MAES, D.G.D.; JANSSENS, G.P.J.; DELPUTTE, P.; LAMMERTYN, A.; KRUIF, A.:

Back fat measurements in sows from three commercial pig herds: relationship with reproductive efficiency and correlation with visual body condition scores. Livest. Prod. Sci. 91 (2004), 57-67

POLEZE, E.; BERNARDI, M.L.; AMARAL FILHA, W.S.; WENTZ, I.; BORTOLOZZO, F.P.:

Consequences of variation in weaning-to-estrus interval on reproductive performance of swine females. Livest. Sci. 103 (2006), 124-130

PRUNIER, A.; DOURMAD, J.Y.; ETIENNE, M.:

Feeding level, metabolic parameters and reproductive performance of primiparous sows. Livest. Prod. Sci. 37 (1993), 185-196

PRUNIER, A.; QUESNEL, H.; MESSIAS DE BRAGANÇA, M.; KERMABON, A.Y.:

Environmental and seasonal influences on the return-to-oestrus after weaning in primiparous sows: a review. Livest. Prod. Sci. 45 (1996), 103-110

REPUBLIC OF SLOVENIA

The Law Regulating the Protection of Animals in Republic of Slovenia (1999), (Zakon o zaščiti živali, Uradni list Republike Slovenije, 510-05/91-1/20, November 18, 1999)

RYDHMER, L.:

Genetics of sow reproduction, including puberty, oestrus, pregnancy, farrowing and lactation. Livest. Prod. Sci. 66 (2000), 1-12

SERENIUS, T.; STADLER, K.J.; BAAS, T.J.; MARBY, J.W.; GOODWIN, R.N.; JOHNSON, R.K.; ROBISON, O.W.; TOKACH, M.; MILLERLL, R.K.:

National pork producers councils maternal line national genetic evaluation program: A comparison of sow longevity and trait associations with sow longevity. J. Anim. Sci. 84 (2006), 2590-2595 
SIMMINS, P.H.; EDWARDS, S.A.; SPECHTER, H.H.:

Growth and body condition of sows given different feeding regimes during the rearing stage and through eight parities when housed in groups with straw bedding. Anim. Prod. 58 (1994), 271-283

SOLANES, F.X.; STERN, S.:

Estimated mature weights and growth curves for large white sows. Acta Agric. Scand., Sect. A, Anim. Sci. 51 (2001), 142-147

SPSS for Windows V 15.0.1

SPSS for Windows. Release 15.0.1., Standard Version, Copyright SPSS Inc. 1989-2006, licensed to University of Maribor, Faculty of Agriculture

STERNING, M.; RYDHMER, L.; ELIASSON, L.; EINARSSON, S.; ANDERSSON, K.:

A study on primiparous sows of the ability to show standing oestrus and to ovulate after weaning influences of loss of body weight and backfat during lactation and of litter size, litter weight - gain and season. Acta Vet. Scand. 31 (1990), 227-236

STERNING, M.; LUNDEHEIM, N.:

Some factors influencing pregnancy rate and subsequent litter size in primiparous sows. Acta Vet. Scand. 36 (1995), 353-365

TANTASUPARUK, W.; DALIN, A.M.; LUNDEHEIM, N.; KUNAVONGKRIT, A.; EINARSSON, S.:

Body weight loss during lactation and its influence on weaning-to-service interval and ovulation rate in Landrace and Yorkshire sows in the tropical environment of Thailand. Anim. Prod. Sci. 65 (2001a), 273-281

TANTASUPARUK, W.; LUNDEHEIM, N.; DALIN, A.M.; KUNAVONGKRIT, A.; EINARSSON, S.:

Weaning-to-service interval in primiparous sows and its relationship with longevity and piglet production. Livest. Prod. Sci. 69 (2001b), 155-162

THAKER, M.Y.C.; BILKEI, G.:

Lactation weight loss influences subsequent reproductive performance of sows. Anim. Prod. Sci. 88 (2005), 309-318

TUCHSCHERER, A.; HÜHN, I.:

Fruchtbarkeitsleistungen von Jungsauen mit unterschiedlicher Seitenspeckdicke vor Beginn der Zuchtbenutzung. Arch. Tierz. 40 (1997) Sonderheft, 205

VALROS, A.; RUNDGREN, M.; ŠPINKA, A.; SALONIEMI, H.; RYDHMER, L.; HULTÉN, F.; UVNÄS-

MOBERG, K.; TOMÁNEK, M.; KREJCI, P.; ALGERS, B.: Metabolic state of the sow, nursing behaviour and milk production. Livest. Prod. Sci. 79 (2003), 155-167

VARGAS, A.J.; BERNARDI, M.L.; WENTZ, I.; BORCHARD NETO, G.; BORTOLOZZO, F.P.:

Time of ovulation and reproductive performance over three parities after treatment of primiparous sows with PG600. Theriogenology 66 (2006), 2017-2023

WÄHNER, M.; ENGELHARDT, S.; SCHNURRBUSCH, U.; GOTTSCHALK, J.; PFEIFFER, H.:

Beziehungen zwischen Kriterien des Fleisch- bzw. Fettansatzes und den 17- $\beta$-Östradiol- bzw. Progesteronkonzentrationen in der Follikelflüssigkeit, im Muskel- und Fettgewebe, der Ovulationspotenz der Fruchtbarkeitsleistung von Jungsauen. Arch. Tierz. 38 (1995), 187-197

WÄHNER, M.; SCHOLZ, H.; KÄMMERER, B.:

Bezeichnung zwischen Futteraufnahme, Seitenspeckdicke und ausgewählten Merkmalen der Aufzuchtleistung laktierender Sauen. Arch. Tierz. 44 (2001a), 639-648

WÄHNER, M.; JOHN A.; HOFFMEYER, C.:

Zum Einfluss des Wachstums und der Seitenspeckdicke auf die Fruchtbarkeits- und Aufzuchtleistung von Jungsauen. I. Mitt.: Vergleich der Merkmale Wachstum, Seitenspeckdicke, Fruchtbarkeit und Aufzuchtleistungen. Arch. Tierz. 44 (2001b), 157-166

WÄHNER, M.: Synchronisation von Zyklus und Ovulation beim Schwein. Tierärztl. Prax. 30 (2002), 252-260

WHITTEMORE, C.:

Nutrition reproduction interactions in primiparous sows. Livest. Prod. Sci. 46 (1996), 65-83

YANG, H.; EASTHAM, P.R.; PHILLIPS, P.; WHITTEMORE, C.T.:

Reproductive performance, body weight and body condition of breeding sows with differing body fatness at parturition, differing nutrition during lactation, and differing litter size. Anim. Prod. Sci. 48 (1989), 181-201

YOUNG, L.G.; KING, G.J.; SHAW, J.; QUINTON, M.; WALTON, J.S.; MCMILLAN, I.: Interrelationships among age, body weight, backfat and lactation feed intake with reproductive performance and longevity of sows. Can. J. Anim. Sci. 71 (1991), 567-575 
Authors:

Prof. Dr. DEJAN ŠKORJANC*

MARKO HOHLER, Univ. Dipl. Eng. Agric.

MAKSIMILJAN BRUS, Univ. Dipl. Eng. Agric.

Faculty of Agriculture

University of Maribor

Vrbanska 30

2000 Maribor

Slovenia

*Corresponding author

email: dejan.skorjanc@uni-mb.si 